\title{
Kondisi Hidrooseanografi Muara Sungai Jelitik, Sungailiat, Bangka Provinsi Bangka Belitung
}

\author{
Edwin Wiguna, Mardi Wibowo*, Reno Arief Rachman, Hilmi Aziz, Sapto Nugroho \\ Balai Teknologi Infrastruktur Pelabuhan dan Dinamika Pantai, Badan Pengkajian dan Penerapan Teknologi \\ Jl. Grafika No. 2 SEKIP Yogyakarta 55284Indonesia \\ Email :mardi.wibowo@bppt.go.id
}

\begin{abstract}
Abstrak
Muara Sungai Jelitik di Sungailiat Bangka merupakan alur pelayaran bagi banyak jenis kapal karena di muara ini terdapat Pelabuhan Perikanan (PPN) Sungailiat.Sedimentasi yang terjadi di muara Sungai Jelitik sangat merugikan, karena ketika air laut surut terendah muara ini tertutup sehingga mengganggu kelancaran lalu lintas kapal dari air kantong ke laut bebas maupun sebaliknya.Pantai Pulau Bangka adalah pantai yang mempunyai arus gelombang dan angkutan sedimen sejajar pantai cukup besar yang dipengaruhi oleh gelombang musim angin barat dan musim angin timur. Guna menjamin kelancaran lalu lintas kapal di lokasi tersebut, maka proses sedimentasi di area tersebut harus dikendalikan sehingga tidak menutup alur pelayaran. Pemahaman tentang dinamika kondisi hidrooseanografi di perairan tersebut diperlukan untuk memilih dan menentukan tindakan pengendalian sedimen. Oleh karena itu perlu adanya survei dan kajian yang bertujuan mengetahui kondisi hidrooseanografi di perairan sekitar muara Sungai Jelitik sebagai bahan pertimbangan untuk menentukan tindakan dan perancangan pengendalian sedimentasi di lokasi tersebut.Metode yang dipakai dalam kajian ini adalah survei dan pemetikan data langsung di lapangan kemudian dilakukan pengolahan dan analisis data hasil survei tersebut. Berdasarkan hasil kajian ini diketahui bahwa kedalaman laut di depan muara Sungai Jelitik bervariasi dari $1 \mathrm{~m}$ hingga $30 \mathrm{~m}$, dengan karakteristik dasar perairan sangat dipengaruhi aktivitas penambangan pasir laut. Tipe pasut di Sungailiat adalah tipe harian tunggal (diurnal) dengan arah arus dominan barat dan timur dengan kecepatan maksimum 16,3 cm/dt. Tinggi gelombang bervariasi antara $0-1,5 \mathrm{~m}$.
\end{abstract}

Kata Kunci : hidrooseanografi, hidrodinamika, pasang surut, diurnal, hindcasting, Sungailiat

\section{Abstract \\ Hydroooseanographic Condition in Muelitik River Estuary, Sungailiat, Bangka, Bangka Belitung Province}

The Jelitik River Estuary at Sungailiat Bangka is a navigation channel for many types of ships because, at this estuary, there is a Sungailiat Fishery Port. Sedimentation that occurs at the mouth of the Jelitik River is very detrimental because when the tide is lowest, the inlet is closed, so disrupted ship traffic. The coast of Bangka Island is a coast that has a massive wave of current and longshore sediment transport that is influenced by the waves of the west wind season and the east wind season. To ensure the smooth flow of ships at that location, the sedimentation process in the area must be controlled so that it does not close the shipping lanes. To select and determine these sediment control measures, an understanding of the dynamics of hydro oceanographic conditions in these waters is needed. Therefore it is necessary to have a survey and study to investigate the condition of hydro oceanography in the waters around the Jelitik River estuary. The study is important for determining the actions and design of sedimentation control in these locations. The method used in this study is surveying and picking data directly in the field, then processing and analyzing the results of the survey data. Based on the results of this study, it is known that the depth of the sea in front of the Jelitik River estuary varies from $1 \mathrm{~m}$ to $30 \mathrm{~m}$, with the basic characteristics of the waters strongly influenced by the activity of sea sand mining. Tidal type in Sungailiat is a single daily type (diurnal) with the direction of dominant currents west and east with a maximum speed of $16.3 \mathrm{~cm} / \mathrm{s}$. Wave height varies between 0-1.5 $\mathrm{m}$.

Keywords: hydrooseanography, hydrodynamics, tides, diurnal, hindcasting, Sungailiat

\begin{tabular}{lcl}
\hline \hline *Corresponding author & http://ejournal.undip.ac.id/index.php/buloma & Diterima/Received :24-05-2019 \\
DOI:10.14710/buloma.v9i1.23363 & & Disetujui/Accepted : 19-11-2019
\end{tabular}




\section{PENDAHULUAN}

Muara Sungai Jelitik di Sungailiat, Bangka merupakan alur masuk bagi banyak jenis kapal, yang meliputi: kapal nelayan yang menuju/dari Pelabuhan Perikanan Nusantara Sungailiat, kapal penambang timah lepas pantai milik PT. Timah dan kapal-kapal rakyat lainnya. Penutupan alur muara secara alami oleh material terangkut (pasir) sangat merugikan, karena mengganggu kelancaran lalu lintas kapal dari air kantong ke laut bebas maupun sebaliknya.

Seiring dengan meningkatnya aktivitas penambangan dan pencarian ikan oleh nelayan di wilayah perairan lepas pantai Sungailiat, maka keberadaan kawasan air kantong dalam mendukung perekonomian masyarakat di wilayah tersebut semakin penting pula, sehingga kondisi alur pelayaran untuk masuk/keluar kapal, yang meliputi lebar dan kedalaman akses tersebut perlu dijaga dan dipelihara sehingga dapat berfungsi dengan baik.

Muara Sungai Jelitik terletak di pantai timur Pulau Bangka (Gambar 1). Kawasan pantai ini merupakan kawasan yang sangat dinamis dengan berbagai ekosisitem yang saling terkait.Perubahan garis pantai merupakan salah satu bentuk dinamisasi kawasan pantai yang terjadi secara terus menerus. Perubahan garis pantai yang terjadi di kawasan pantai berupa pengikisan badan pantai (abrasi) dan penambahan badan pantai (sedimentasi atau akresi) (Suhana, 2015).Prosesproses tersebut terjadi akibat dari pergerakan sedimen, arus dan gelombang yang berinteraksi dengan kawasan pantai secara langsung.Selain faktor-faktor tersebut, perubahan garis pantai dapat terjadi akibat faktor antropogenik, seperti aktivitas manusia disekitarnya (Wibowo, 2012). Pantai Pulau Bangka adalah pantai yang mempunyai arus gelombang dan angkutan sejajar pantai cukup besar dan dipengaruhi oleh gelombang musim angin barat dan musim angin timur (Azizi, 2017). Keseimbangan alamiah akan terbentuk dengan angkutan sedimen pada kedua arah tersebut. Berdasarkan hasil penelitian Sabri (2017) menyatakan bahwa erosi pada Sub DAS PepabriJelitik masuk kategori berat dengan nilai erosi sebesar 270,083 ton/ha/tahun dan sedimentasi pada muara Sungai Jelitik ini sebesar 52.753,60 ton/tahun, sehingga menganggu lalu lintas kapal yang akan masuk maupun keluar dari air kantong.

Untuk menjamin kelancaran lalu lintas kapal di lokasi tersebut, maka proses sedimentasi di area tersebut harus dikendalikan sehingga tidak menutup alur pelayaran. Untuk memilih dan menentukan tindakan pengendalian sedimen tersebut diperlukan pemahaman tentang dinamika kondisi hidrooseanografi di perairan tersebut. Dinamika perairan tersebut dapat diketahui dengan mengenal parameter oseanografi perairan yang di maksud (Pariwono, 2002; Kumajas et al., 2007).

Parameter hidrooseanografi yang penting untuk diketahui antara lain adalah batimetri, pasang surut, arus dan gelombang. Batimetri adalah kedalaman laut yang dinyatakan dalam angka kedalaman atau kontur kedalaman yang diukur terhadap datum vertikal tertentu.

Pasang surut adalah fluktuasi muka air laut karena adanya gaya tarik benda-benda di langit, terutama matahari dan bulan terhadap massa air laut di bumi. Pengetahuan tentang pasang surut (elevasi muka air tertinggi dan terendah) sangat penting dalam perencanaan bangunan pantai dan pelabuhan (Triatmodjo, 1999 dan Triatmodjo, 2012). Pasang surut sangat mempengaruhi kegiatan manusia yang hidup di pantai dan sangat diperlukan oleh berbagai aspek yang luas seperti pelayaran tata letak pelabuhan, persebaran polutan, pengembangan perikanan, dll (Yona et al., 2017).

Arus laut adalah pergerakan transportasi air laut. Arus air laut terutama dipengaruhi oleh gerakan angin dan perbedaan panas di lautan. Arus laut lebih efektif sebagai media penyebaran dan pengenceran polutan yang masuk lingkungan laut (Mukhtasor, 2006).Selain itu arus juga sangat dipengaruhi oleh pasang surut air laut.Arus pasang surut berperan penting sebagai pengangkut zat hara dan plankton, selain itu juga berperan penting untuk mengencerkan dan menggelontorkan limbah yang sampai di laut.(Mukhtasor, 2006).

Gelombang laut merupakan pergerakan air laut secara naik dan turun dengan arah tegak lurus permukaan air laut dan membentuk kurva sinusoidal (Yona et al., 2017). Gelombang adalah salah satu bentuk energi yang dapat membentuk pantai, menimbulkan arus dan transpor sedimen dalam arah tegak lurus dan sepanjang pantai serta menyebabkan gaya-gaya yang bekerja pada bangunan pantai. Berdasarkan pembangkitnya gelombang ada beberapa macam seperti gelombang angin, gelombang pasang surut gelombang tsunami, (Triatmodjo, 1999; Triatmodjo, 2012; Hidayat, 2005).

Tujuan kajian ini adalah untuk mengetahui kondisi hidrooseanografi dan pola hidrodinamika di muara Sungai Jelitik sebagai bahan pertimbangan untuk menentukan tindakan dan perancangan pengendalian sedimentasi di lokasi tersebut. 


\section{MATERI DAN METODE}

Survei ini dilaksanakan pada bulan April Mei 2018, bertempat di perairan laut sekitar muara S Jelitik, Kec. Sungailiat, Kab. Bangka, Provinsi Bangka Belitung. Pengolahan dan analisis data dilakukan di Balai Teknologi Infrastruktur Pelabuhan dan Dinamika Pantai.Metode pengukuran batimetri menggunakan echosounder atau alat perum gema yang memanfaatkan gelombang akustik (single beam beamecho sounder).

Metode pengukuran pasang surut dilakukan secara manual dan otomatis.Metode manual adalah dengan pencatatan langsung pada rambu ukur yang terpasang.Pengamatan manual dilakukan pada saat pengukuran batimetri dan pada saat untuk kontrol pencatatan harian.Pencatatan secara otomatis diatur dengan interval waktu perekaman selama 15 menit.Sedangkan pengukuran otomatis dilakukan dengan menggunakan tidemaster yang tranducernya sudah dikalibrasi terhadap titik nol rambu ukur.

Metode pengukuran arus dilakukan secara otomatis dengan men-deploy ADCP bottom mounted dan vessel mounted pada beberapa lokasi pengukuran. Survei arus di perairan sekitar muara S. Jelitik, dilakukan di 6 titik yang tersebar di dalam kolam labuh dan di area muara Sungai Jelitik.Adapun lokasi keenam titik tersebut ditunjukkan pada gambar di bawah ini. Selain dengan ADCP pengukuran juga dilakukan dengan flowtrack terutama di alur sungai (lokasi A5 dan A6).Survei arus dilaksanakan pada tanggal 29-30 April 2018 untuk kondisi neap dan tanggal 5-6 Mei 2018 untuk kondisi spring.

Untuk data gelombang dianalisis berdasarkan data angin (wind hindcasting) Juli 2017 - Juni 2018 dari NOAA dengan metode SMB (Sverdrup Munk Bretschneider) (USACE, 1977). Data angin didapat dari NOAA yang bersumber dari stasiun angin Pangkalpinang. Data ini berisi waktu, kecepatan dan arah angin setiap 3 jam (NOAA, 2018).

\section{HASIL DAN PEMBAHASAN}

Berdasarkan hasil survei, pengolahan dan analisis data yang telah dilakukan maka kondisi hidrooseanografi di perairan sekitar muara Sungai Jelitik diuraikan sebagai berikut.

Ruang lingkup area survei ditentukan berdasarkan area yang merepresentasikan dinamika sedimentasi di Muara Sungai Jelitik. Dari muara Sungai Jelitik sejauh $\pm 1,5 \mathrm{~km}$ sejajar garis pantai baik ke arah barat laut ataupun arah tenggara, ke arah laut $\pm 3 \mathrm{~km}$ dan masuk ke Sungai Jelitik sejauh perahu yang digunakan mampu melakukan penetrasi.

Gambar 2 menunjukkan hasil pemetaan batimetri. Berdasarkan hasil survei, didapatkan data kedalaman laut sebanyak 6498 titik kedalaman. Dalam cangkupan area yang direncanakan tidak semua dapat dilakukan pengukuran dikarenakan berbagai faktor. Pengukuran ke arah sungai memiliki keterbatasan dalam hal penetrasi ke areal dangkal. Selain itu pengukuran batimetri di bawah kedalaman 1 meter cenderung menghasilkan data yang tidak valid, sedangkan pengukuran batimetri di perairan pantai memiliki kendala adanya beberapa kapal besar yang sedang melakukan aktifitas tambang sehingga pengukuran kedalaman di tempat tersebut tidak bisa dilakukan. Hal ini menyebabkan hasil peta batimetri seolah berlubang karena tidak memiliki data.Kotak A dan B pada gambar 8 menunjukan lokasi yang tidak memiliki data.

Berdasarkan hasil survei batimetri diketahui bahwa kedalaman perairan di sekitar muara Sungai Jelitik saat survei berkisar antara 1-29 m. Pola batimetri di sekitar pantai masih bergradasi sejajar dengan garis pantai meskpiun ada spot-spot yang berupa ceruk-ceruk yang cukup dalam karena penambangan pasir timah. Ke arah laut lepas pola batimeteri cenderung tidak mengikuti garis pantai. Pola batimetri yang spot-spot ini disebabkan banyak dan tingginya intensitas penambangan pasir timah baik oleh kapal hisap milik perusahaan maupun oleh masyarakat umum. Bahkan pada lokasi tertentu terdapat ceruk yang kedalamannya mencapai $30 \mathrm{~m}$ padahal batimetri di sekitarnya hanya sekitar $13 \mathrm{~m}$. Kondisi batimetri bersifat sementara karena pengambilan pasir laut ini lokasinya berpindah dari waktu ke waktu. Menurut penelitian Gaol (2017) kedalaman perairan di sekitar pantai Pulau Bangka berkisar antara 1-33,2 $\mathrm{m}$.

\section{Pasang Surut}

Pengukuran pasang surut dilakukan di Dermaga Pelabuhan Perikanan Nusantara Sungailiat, Kab. Bangka dan dilaksanakan selama 15 hari, yaitu pada tanggal 24 April 2018 sampai dengan 9 Mei 2018. Berdasarkan hasil pencatatan otomatis Tidemaster pada tanggal 24 April 2018 sampai dengan 9 Mei 2018, diperoleh data dan pola pasang surut selama 15 hari (Gambar 3).

Kondisi pasang surut di Sungailiat menunjukkan terjadinya kondisi sekali pasang dan sekali surut dalam satu hari (diurnal). Rata-rata elevasi muka air terletak pada nilai $1.42 \mathrm{~m}$ pada palm pasang surut. Analisis harmonik terhadap 
data hasil pencatatan dilakukan untuk mendapatkan nilai elevasi muka air penting seperti Highest High Water Level, Mean Higher High Water, Mean Lower High Water, Mean Higher Low Water, Mean Lower Low Water dan Lowest Low Water Level. Hasil analisis merupakan konstanta pasang surut yang dipergunakan dalam perhitungan elevasi penting pasang surut di Sungailiat seperti terdapat pada Tabel 1.

Tabel 1. Konstanta pasang surut di Sungailiat

\begin{tabular}{cccc}
\hline No & Name & Amplitudo & Phase \\
\hline 1 & M2 & 0.0383 & 163.62 \\
2 & S2 & 0.0324 & -135.11 \\
3 & K1 & 0.6018 & 137.39 \\
4 & O1 & 0.4144 & 61.12 \\
5 & F4 & 4.6569 & -8.19 \\
6 & F6 & 2.5524 & 160.95 \\
\hline
\end{tabular}

Berdasarkan konstanta pasang surut tersebut, dapat dihitung nilai elevasi muka air penting.Angka-angka penting pasang surut di perairan Sungailiat terlihat seperti pada Tabel 2.Tipe pasang surut dapat ditentukan melalui perhitungan nilai Bilangan Formzahl (F). Formzahl adalah bilangan untuk menentukan tipe pasang surut. Bilangan formzahl memiliki range tertentu untuk menentukan tipe pasang surut suatu wilayah.

Nilai Bilangan Formzahl di perairan Sungailiat dari hasil perhitungan di adalah sebesar 14.37 sehingga tipe pasut di Sungailiat dapat digolongkan sebagai tipe harian tunggal (diurnal) dengan tunggang pasang sebesar 2,18 m. Hal ini sesuai dengan hasil penelitian Pamungkas (2018) yang menyatakan bahwa pasang surut di perairan Bangka baik selatan dan utara bertipe diurnal dengan kategori makro-tidal dengan tunggang pasang 2,5 $\mathrm{m}$. Sesuai juga dengan hasil pemodelan hidrodinamika pasang surut yang dilakukan oleh Radjawane et al. (2018) yang menyatakan bahwa pola pasang surut di perairan Bangka Belitung didominasi oleh tipe harian tunggal (diurnal).

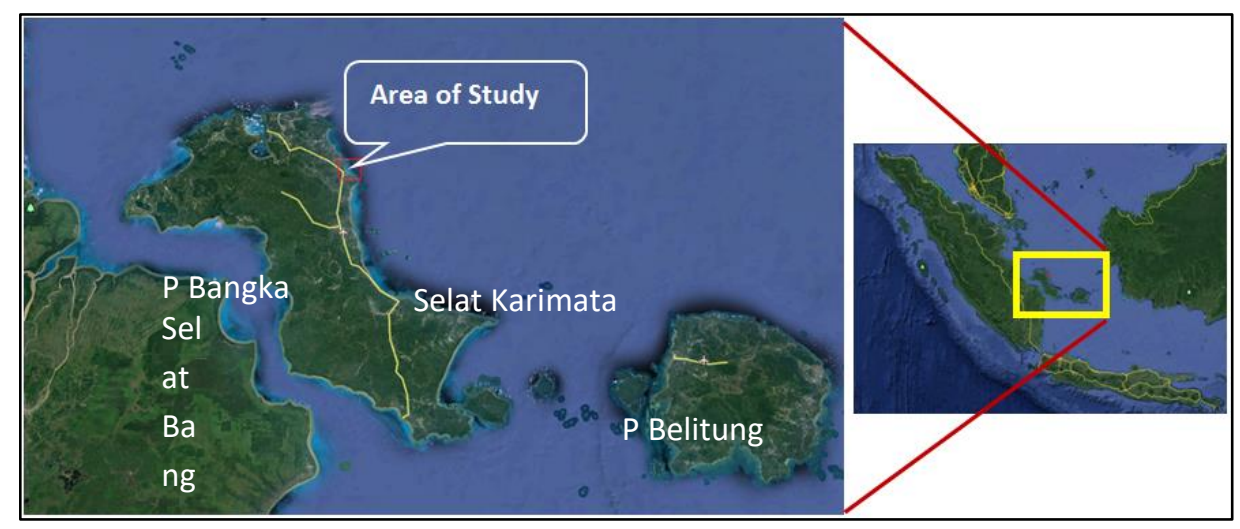

Gambar 1.Lokasi kajian

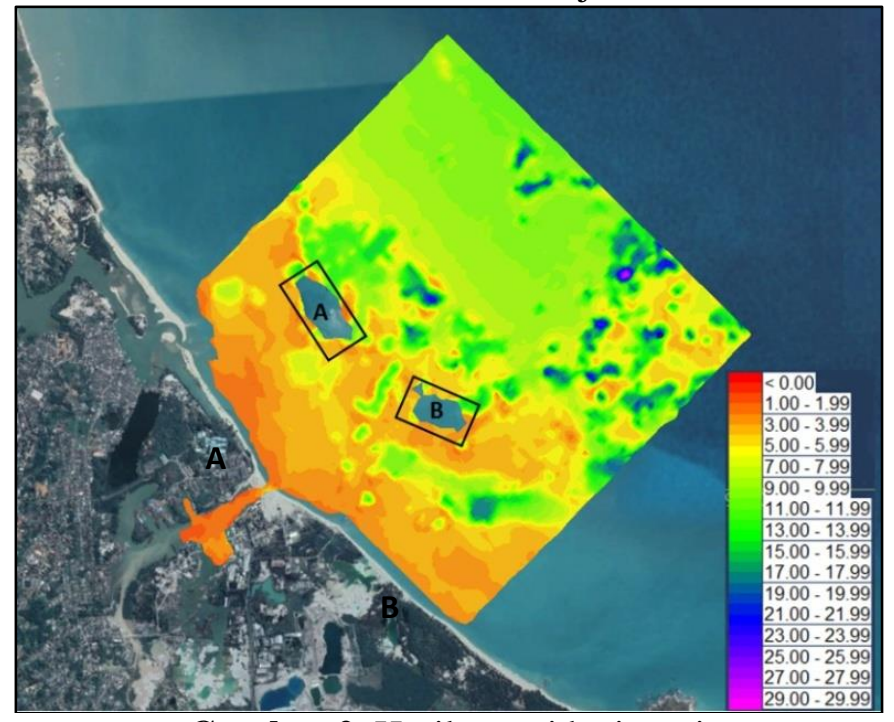

Gambar 2. Hasil survei batimetri 


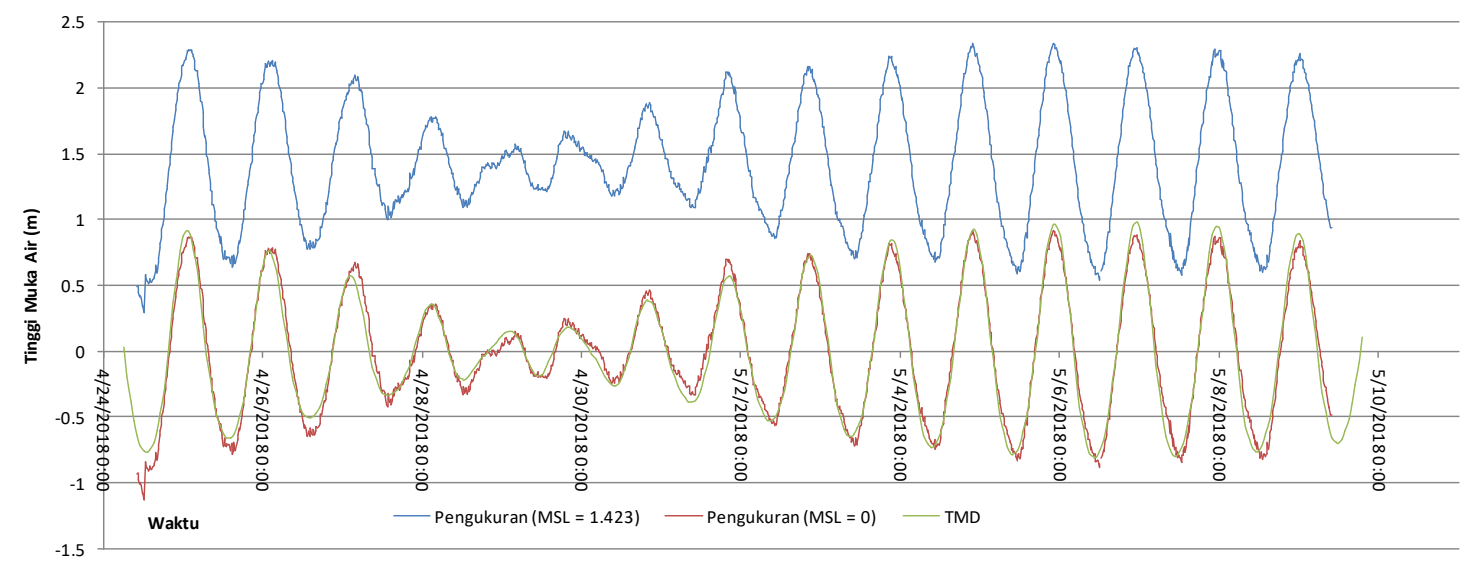

Gambar 3. Grafik Pasang Surut Sungailiat 24 April - 9 Mei 2018

Tabel 2. Angka Penting Pasang Surut Sungailiat

\begin{tabular}{lcc}
\hline \multicolumn{1}{c}{ Elevasi Penting } & Terhadap Palm (m) & Terhadap MSL (m) \\
\hline HHWL (Highest High Water Level) & 2.51 & 1.09 \\
MHHW (Mean Higher High Water) & 2.47 & 1.05 \\
MLHW (Mean Lower High Water) & 2.40 & 0.98 \\
MSL (Mean Sea Level) & 1.42 & 0.00 \\
MHLW (Mean Higher Low Water) & 0.44 & -0.98 \\
MLLW (Mean Lower Low Water) & 0.37 & -1.05 \\
LLWL (Lowest Low Water Level) & 0.33 & -1.09 \\
\hline
\end{tabular}

\section{Arus}

Berdasarkan hasil pengukuran, arah arus cenderung bolak-balik mengikuti kondisi pasang surut muka air laut karena pada kondisi pasang arus cenderung ke arah selatan-barat daya dan pada saat surut cenderung ke arah timur laut. Kecepatan arus berkisar antara 5-70 cm/dt. Kecepatan arus yang besar $(60-70 \mathrm{~m} / \mathrm{dt})$ terjadi pada saat neap (baik ketika menuju pasang maupun surut) dan pada saat spring kecepatan arus relatif kecil (Gambar 5). Berdasarkan hasil penelitian Pamungkas (2017) kecepatan arus di perairan Bangka berkisar antara 0,2- 0,3 $\mathrm{m} / \mathrm{dt}$.

Berdasarkan hasil pengukuran arus di alur $\mathrm{S}$ Jelitik dengan menggunakan flowtrack diketahui bahwa arus di alur sungai sangat dipengaruhi oleh pasang surut air laut dimana ketika pasang arah arus menuju hulu dan sebaliknya ketika surut. Kecepatan arus berkisar antara 11,2-33,6 cm/dt (Gambar 6).

\section{Gelombang}

Pola angin selama 2015 hingga 2018 untuk Pangkalpinang dan sekitarnya ditunjukkan oleh Gambar 7.Seperti ditunjukkan pada Gambar 7, angin yg bertiup di kawasan Sungailiat didominasi oleh angin dari timur-tenggara dengan kecepatan antara $2-6 \mathrm{~m} / \mathrm{s}$.

Pada musim Barat (Des 2017 s/d Jan 2018), angin bertiup dengan arah dominan dari arah barat dan barat laut dengan kecepatan antara 2-6 m/s seperti ditunjukkan pada Gambar 8(a). Sedangkan pada musim Timur, angin bertiup dengan arah dominan dari timur dan tengara dengan kecepatan antara 2-6 m/s, seperti ditunjukkan pada Gambar 8(b).

Kondisi gelombang di kawasan perairan Sungailiat diprediksi (hindcasting) menggunakan data angin dan panjang fetch seperti pada Gambar 9 berikut. Garis fetch yang tersebar ke berbagai arah kemudian dikelompokkan menjadi 8 (delapan) arah mata angin, sehingga didapatkan panjang efektif nya pada 8 arah trersebut seperti ditunjukkan pada tabel 3 berikut. Hindcasting gelombang dilakukan di lepas pantai pada lokasi dengan kedalaman sekitar 15 meter, untuk periode antara Juli 2017 s/d Juni 2018. Dari hasil hindcasting gelombang, diperoleh data temporal variasi tinggi, periode dan arah datang gelombang selama periode tersebut. Sesuai dengan data angin yang ada, interval data temporal (time series) ini adalah 3 jam. Mawar gelombang hasil hindcasting di Sungailiat terlihat seperti pada Gambar 10. 


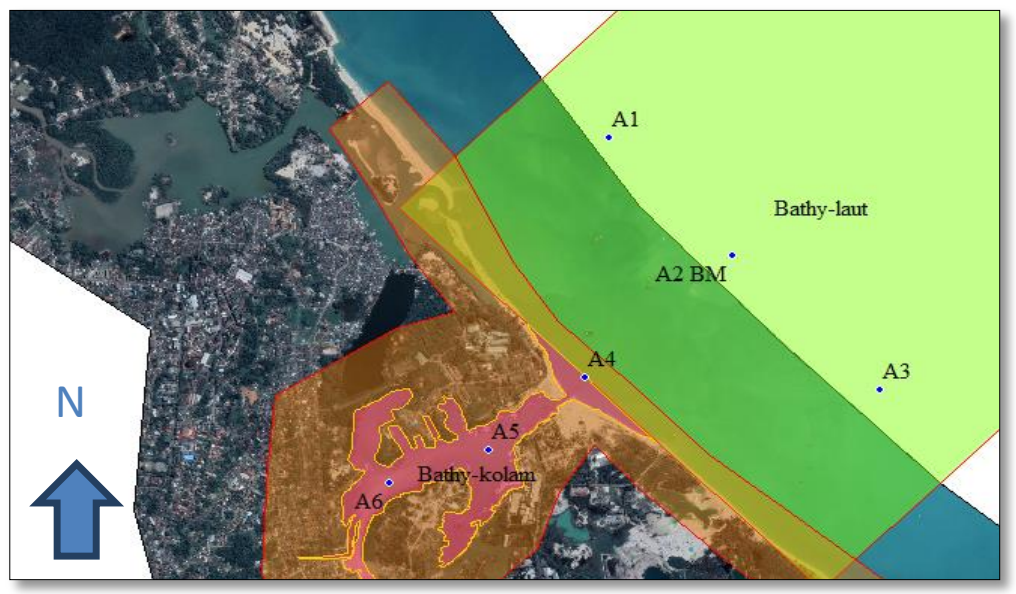

Gambar 4. Lokasi titik pengukuran arus

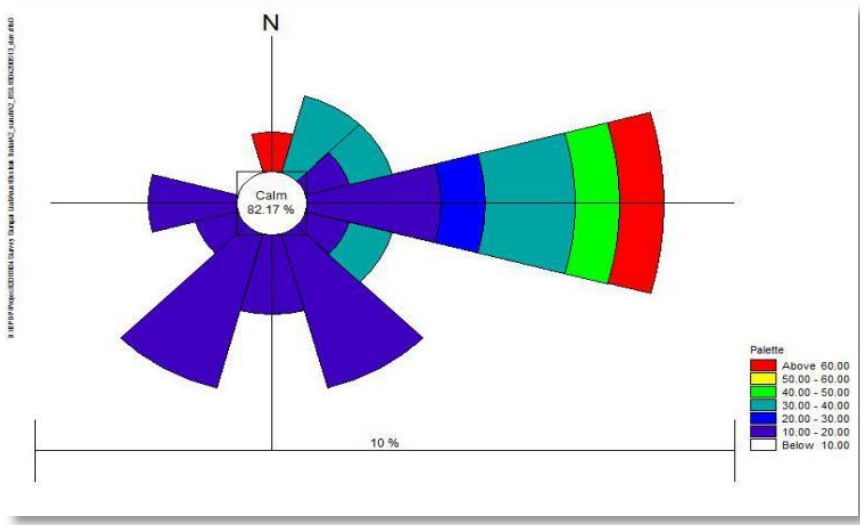

(a)

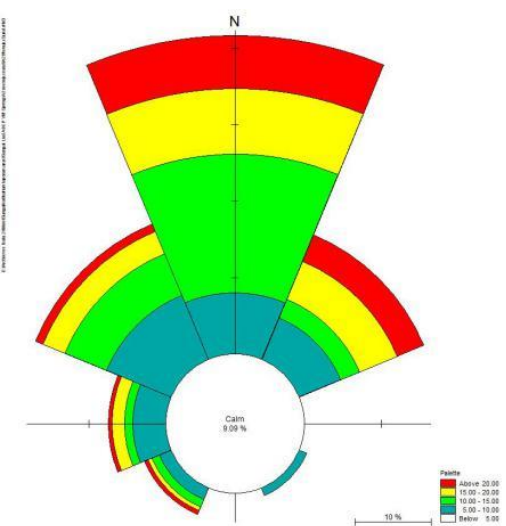

(b)

Gambar 5. Mawar arus pada lokasi A2 (a) kondisi neap menuju surut, (b) kondisi spring menuju surut

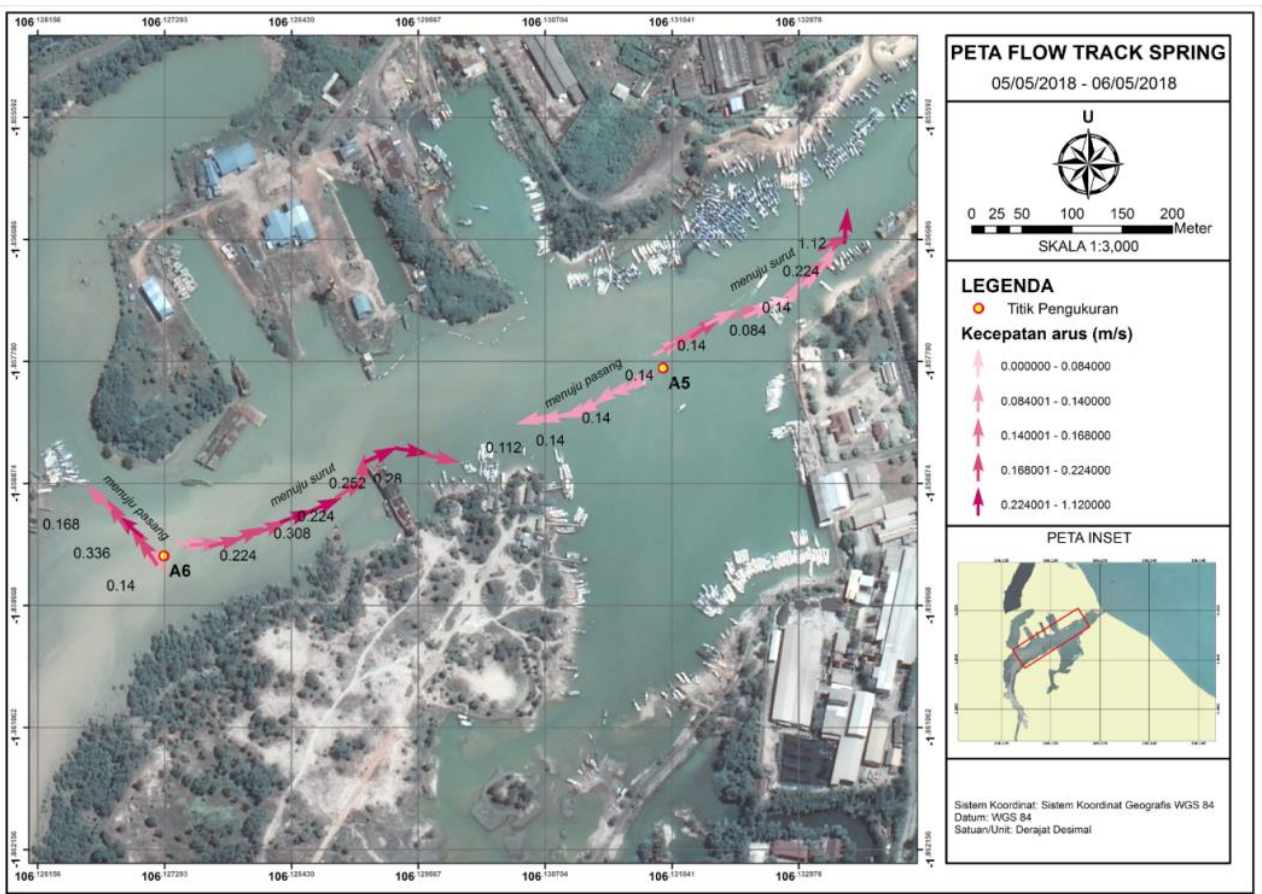

Gambar 6. Hasil pengukuran arus di alur S Jelitik dengan flowtrack 


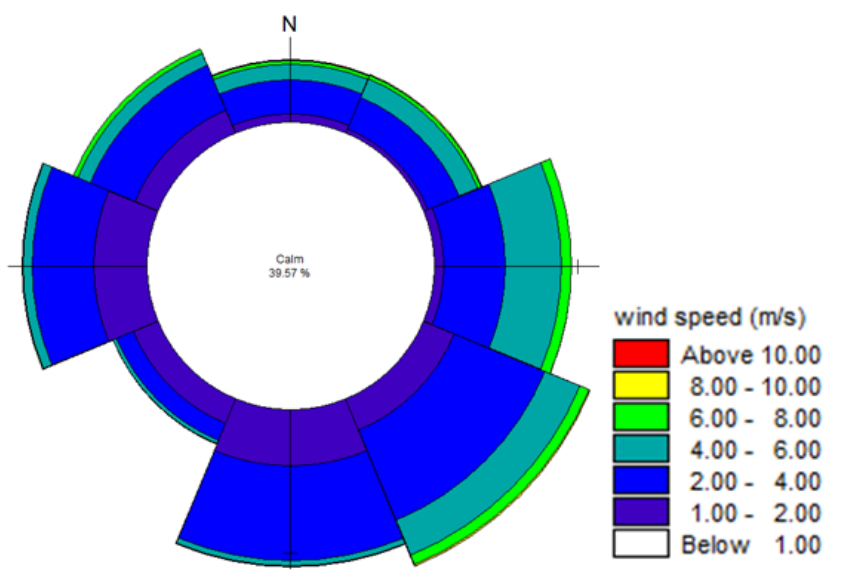

Gambar 7. Pola angin di Pangkalpinang dan sekitarnya dari 2015 s/d 2018

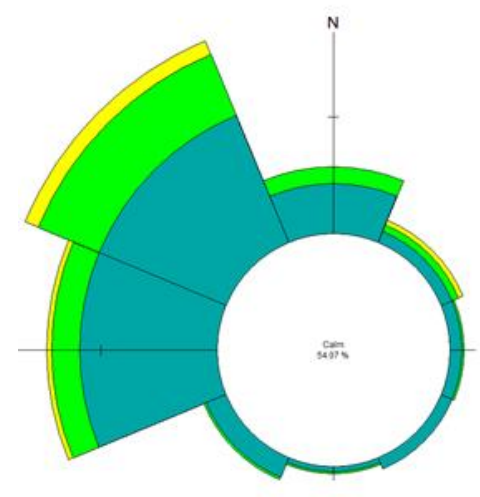

(a)

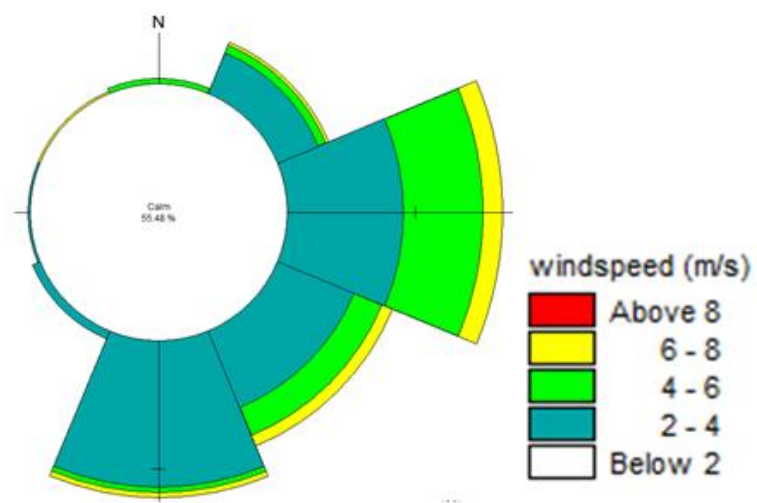

(b)

Gambar 8. Pola angin di Pangkalpinang dan sekitarnya pada (a) musim barat dan (b) musim timur

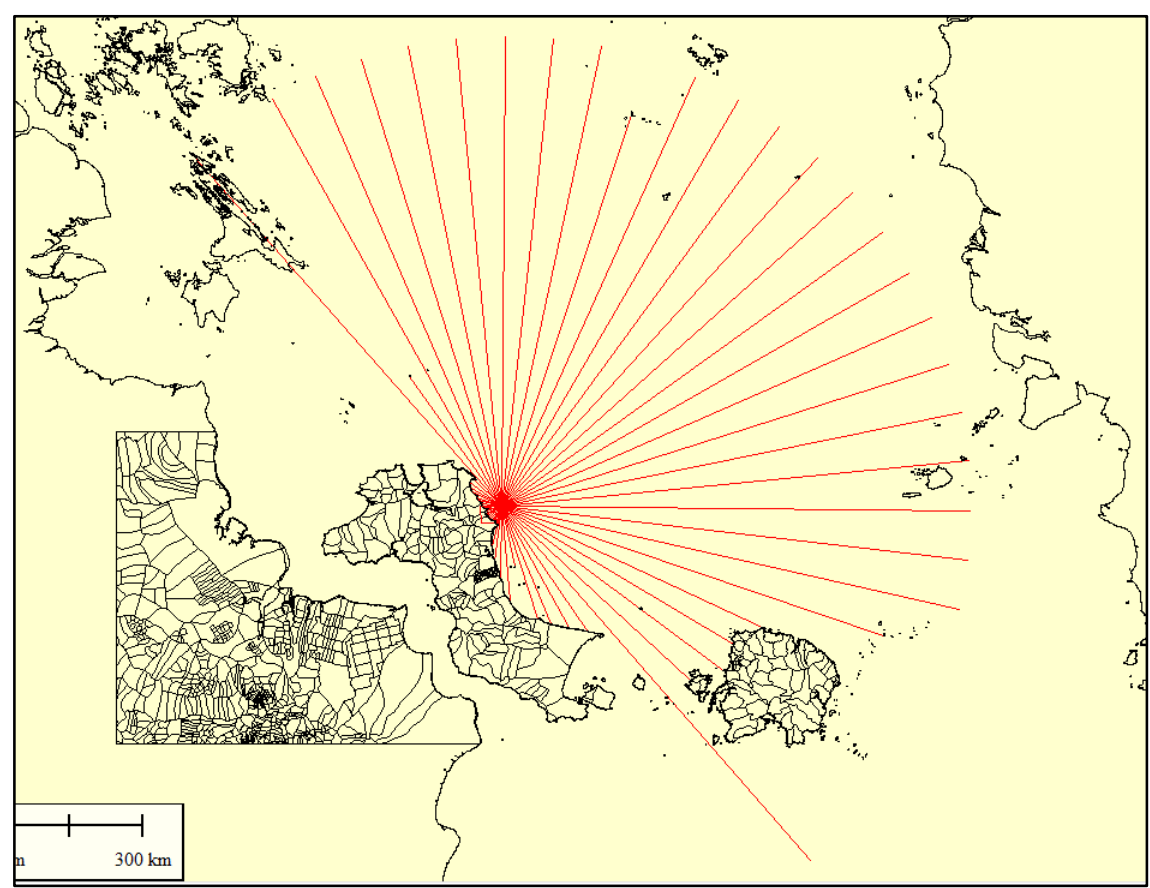

Gambar 9. Garis fetch ditarik dari Sungailiat ke arah perairan terbuka 
Tabel 3. Panjang efektif fetch Sungailiat

\begin{tabular}{|c|c|c|c|}
\hline No & Arah & Kisaran Sudut $\left({ }^{\circ}\right)$ & Panjang Fetch Efektif (km) \\
\hline 1 & Utara & $337,5-22,5$ & 295,59 \\
\hline 2 & Barat laut & $292,5-337,5$ & 150,66 \\
\hline 3 & Barat & $247,5-292,5$ & 16,48 \\
\hline 4 & Barat Daya & $202,5-247,5$ & 15,44 \\
\hline 5 & Selatan & $157,5-202,5$ & 60,73 \\
\hline 6 & Tenggara & $112,5-157,5$ & 167,47 \\
\hline 7 & Timur & $67,5-112,5$ & 251,77 \\
\hline 8 & Timur Laut & $22,5-67,5$ & 300,00 \\
\hline
\end{tabular}

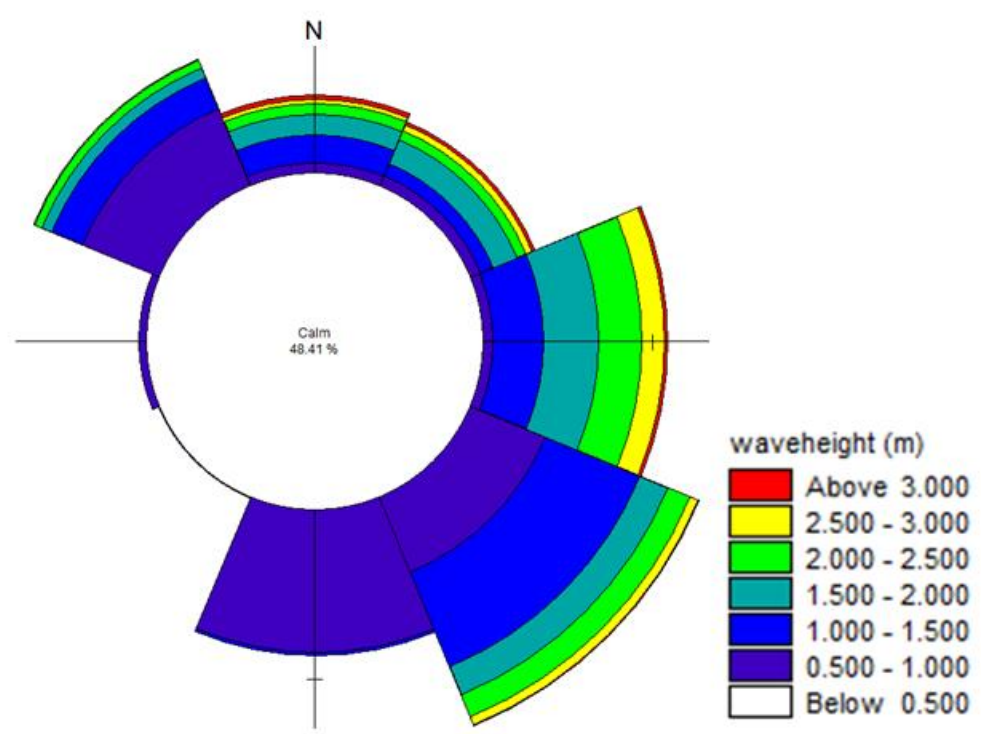

Gambar 10.Hasil hindcasting gelombang periode Juni 2017 s/d Juni 2018 di titik pembangkitan (pada kedalaman sekitar $15 \mathrm{~m}$ )

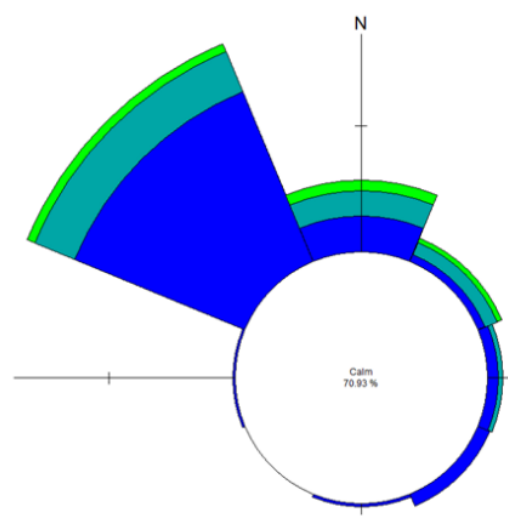

(a)

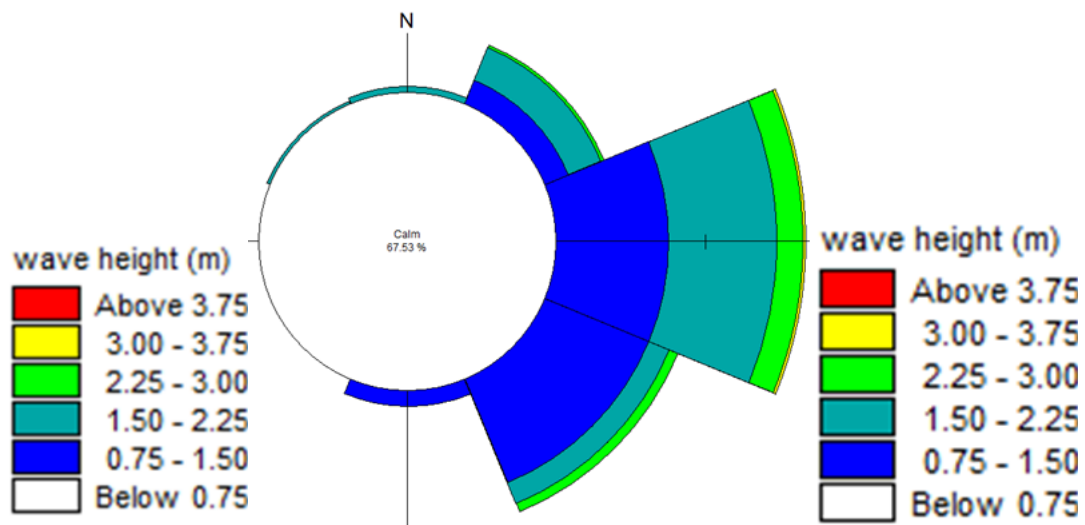

(b)

Gambar 11.Hasil hindcasting gelombang untuk periode (a) musim barat dan (b) musim timur di titik pembangkitan (pada kedalaman sekitar $15 \mathrm{~m}$ ) 
Seperti ditunjukkan pada Gambar 10, gelombang yang dibangkitkan oleh angin di perairan Sungailiat (sekitar $10 \mathrm{~km}$ lepas pantai), terjadi dari berbagai arah dengan ketinggian dari 0 hingga $1,5 \mathrm{~m}$. Berdasarkan hasil penelitian Pamungkas (2017) tinggi gelombang di perairan Pulau Bangka utara berkisar 0,1-0,5 m dan di bagian selatan $0,1-0,3 \mathrm{~m}$. Gelombang dengan tinggi lebih dari $2 \mathrm{~m}$ terjadi dari arah tenggara, timur dan utara. Hasil penelitian Sachoemar et al. (2005) di perairan Bangka gelombang besar terjadi pada bulan September - Maret dengan ketinggian lebih dari $1 \mathrm{~m}$ dengan periode 5-7 detik. Gelombang tertinggi terjadi pada bulan Januari atau Februari dengan ketinggian mencapai $2 \mathrm{~m}$. Sedangkan kondisi gelombang pada musim barat dan musim timur ditunjukkan pada Gambar 11.

\section{KESIMPULAN}

Kedalaman laut di depan muara Sungai Jelitik bervariasi dari 1-30 m, dengan karakteristik dasar perairan artificial, dengan morfologi dasar perairan yang sangat bervariasi. Hal ini disebabkan oleh aktivitas penambangan timah di kawasan perairan ini. Morfologi dasar perairan ini sangat dimungkinkan selalu mengalami perubahan seiring dengan aktivitas penambangan tersebut.Tipe pasut di Sungailiat dapat disimpulkan sebagai tipe harian tunggal dengan nilai $\mathrm{F}$ hasil perhitungan adalah sebesar 14.37 dengan tunggang pasang sebesar 2,18 $\mathrm{m}$. Arah arus pasang surut dominan di dalam alur Sungai Jelitik adalah arah barat dan timur yaitu keluar dan masuk muara sungai. Sedangkan arus di perairan laut dominan arah utara dan selatan dengan kecepatan bervariasi. Arus dengan kecepatan maksimal adalah $16.3 \mathrm{~cm} / \mathrm{s}$ dengan arah dominan ke utara yaitu pada saat kondisi spring.

\section{UCAPAN TERIMA KASIH}

Terima kasih kepada jajaran managemen Balai Teknologi Infrastruktur Pelabuhan dan Dinamika Pantai-BPPT dan kepada seluruh pelaksana kegiatan Pengkajian dan Penerapan Teknologi Rekayasa Industri Maritim-BPPT TA 2018.

\section{DAFTAR PUSTAKA}

Azizi, M.I., Hariyadi \& Atmodjo, W., 2017. Pengaruh Gelombang Terhadap Sebaran Sedimen Dasar di Perairan Tanjung Kalian Kabupaten Bangka Barat, Journal of Oceanography,6(1):165-175.

Gaol, A.S.T., Diansyah, G. \& Purwiyanto, A.I.S., 2017. Analisis Kualitas Air laut di Perairan
Selat Bangka Bagian Selatan, Maspari Journal, 9(1):9-16.

Hidayat N., 2005. Kajian Hidro-oseanografi Untuk Deteksi Proses-Proses Fisik di Pantai, Jurnal Smartek, 3(2):73-85.

Kumajas, M., Kumaat, J.C. \& Moningkey, A. 2007. Studi tentang kondisi Hidro-Oseanografi dan Bathimetri Pantai Bajo-Popareng, Kabupaten Minahasa Selatan, Jurnal Geografi dan Pembangunan Wilayah No III Tahun 2007, Universitas Negeri Manado.

NOAA., 2018. NNDC Climate Data Onlie diakses dari https://www7.ncdc.noaa.gov/CDO/data product pada tanggal 15 Juli 2019.

Pamungkas A., 2018. Karakteristik Parameter Oseanografi (Pasang Surut, Arus dan Gelombang) di Perairan Utara dan Selatan Pulau Bangka, Buletin Oseanografi Marina, 7(1):51-58. DOI:10.14710/buloma.v7i1.19042

Pariwono J.I, 2002. Kondisi Oseanografi Perairan Pesisir Teluk Lampung. Proyek Pesisir Publication, Tecnical Report (TE-99/12-I). Coastal Resources Centre, University Rhode of Island. Jakarta, Indonesia. 28 Halaman.

Radjawane, I.M., Saputro, B.S.C. \& Egon, A., 2018, Model Hidrodinamika Pasang Surut di Perairan Kepulauan Bangka Belitung, Jurnal Teknik Sipil - Jurnal Teoritis dan Terapan Bidang Rekayasa Sipil, 25 (2):121-128. DOI: 10.5614/jts.2018.25.2.5.

Sabri, F., 2017, Kajian Erosi dan Sedimentasi Akibat Perubahan Tataguna Lahan Daerah Aliran Sungai (Studi kasus DAS Betung, Sub DAS Pebari-Jelitik, Kabupaten Bangka), Prosiding Seminar nasional Pengelolaan DAS Secara Terpadu Tahun 2017, Pekanbaru 27 November 2017, Universitas Riau.

Sachoemar, S.I. \& Kristijono, A., 2005, Evaluasi Kondisi Lingkungan Perairan Estaria Teluk Klabat, Bangka pada Musim Timur, Jurnal Teknologi Lingkungan, 6(3):438-445.

Suhana, M.P., 2015. Kajian Hidro-Oseanografi untuk Deteksi Proses-Proses Dinamika Pantai (Abrasi dan Sedimentasi). Pascsarjana Ilmu Kelautan Institut Pertanian Bogor.

Triatmodjo, B. 1999.Teknik Pantai Cetakan ke 8 Tahun 2016, Beta Offset.

Triatmodjo, B. 2012.Perencanaan Bangunan Pantai Cetakan ke 3 Tahun 2014, Beta Offset.

U.S. ArmyCoastal Engineering Research Center. 1977. Shore Protection Manual. Fort Belvoir, VA, 3 volumes, 3rd edition.

Wibowo, Y.A. 2012. Dinamika Pantai (Abrasi dan Sedimentasi). Fakultas Teknik dan Ilmu Kelautan. Universitas Hang Tuah. Surabaya. 
Yona, D., Sartimbul, A., Sambah, A.B., Hidayati, N., Harlyan, L.I., Sari, S.H.J., Fuad, M.A.Z. \&
Rahman, M.A. 2017. Fundamental Oseanografi. UB Press - Universitas Brawijaya. 